Int. J. Dev. Biol. 48: 607-612 (2004)

doi: $10.1387 / \mathrm{ijdb} .041827 \mathrm{jb}$

Essay

\title{
Yves Delage (1854-1920) as a forerunner of modern nuclear transfer experiments
}

\author{
JEAN-CLAUDE BEETSCHEN *,1 and JEAN-LOUIS FISCHER ${ }^{\#, 2}$ \\ ${ }^{1}$ Centre de Biologie du Développement, Université Paul-Sabatier, Toulouse, France and \\ ${ }^{2}$ Centre Alexandre Koyré, Museum National d'Histoire Naturelle, Paris, France
}

\begin{abstract}
It is generally considered that animal cloning by nuclear transfer originated in proposals made by Hans Spemann (1936), following his experiments on delayed nucleation in the newt egg, which were preceded by similar attempts using the sea-urchin egg (Loeb, 1894). Briggs and King (1952) were the first to succeed in transplanting blastula and gastrula nuclei into the enucleated frog egg and in obtaining a significant number of normal tadpoles by means of this technique. We present evidence that much earlier (1895) Yves Delage (1854-1920), a French biologist, had clearly formulated the same experimental project of nuclear transfer, as a means to test Weismann's theory of cell differentiation during embryonic development. This was also Spemann's motivation. Both Delage and Spemann were aware of Loeb's experiments (1894), in which delayed nucleation in the sea-urchin egg was found to result in twin larvae. It is difficult to decide whether Delage's project was influenced by Loeb's findings. On the other hand, it seems that Spemann was not aware of Delage's proposal, since he did not express his own ideas on extended nuclear transfer before 1936. Finally, neither Delage nor Spemann imagined that nuclear transfer could be a means of obtaining groups of genetically identical animals (reproductive cloning).
\end{abstract}

KEY WORDS: nuclear transfer, cloning, Delage, Spemann

\begin{abstract}
Although it is commonly believed that Hans Spemann, in the early decades of the $20^{\text {th }}$ century, pioneered the ideas of nuclear transplantation and reproductive cloning, a French biologist, Yves Delage (1854-1920), had proposed much earlier (1895) the concept of nuclear equivalence and suggested experiments of nuclear transfer.
\end{abstract}

\section{Introduction}

Normal development up to the tadpole stage following transplantation of a nucleus taken from an early embryonic cell (blastula, gastrula) into an unfertilized, enucleated, activated egg was obtained for the first time in the frog Rana pipiens by Briggs and King (1952), who thus succeeded in cloning a vertebrate by nuclear transfer. That experimental technique had, however, been imagined previously by several investigators (see Mc Kinnell, 1978 , for a detailed review), of whom Hans Spemann, recipient of the 1935 Nobel Prize of Medicine and Physiology for his work on embryonic inductions and the "organizer" concept, has been considered the main pioneer for having explicitly postulated such an experiment in a vertebrate (Spemann, 1936, 1938). During the last few years, Spemann's original responsibility in instigating mammalian cloning experiments, including their controversial extension to human beings, has been frequently cited. However, it must be emphasized that the primary aim of nuclear transfer, as imagined by Spemann, was not to obtain groups of genetically identical animals, but to test one of Weismann's hypotheses $(1892,1893)$. According to Weismann's germ plasm theory, cell differentiation was the consequence of unequal nuclear division occurring early during cleavage and embryonic development. The resulting nuclear differences would lead to the emergence of correspondingly different cell types. It appears that the first attempt to test the respective roles of nucleus and cytoplasm in heredity by nuclear transfer experiments was made by Rauber (1886). Using two syringes, this author exchanged the zygotic nuclei between a frog egg and a toad egg one hour after they had been fertilized. It is not surprising that such rough treatment resulted in the developmental arrest of both eggs. The disappointed author could only theorize about a mixed nucleo-cytoplasmic contribution to hereditary transmission. In the same article, Rauber claimed priority over Weismann for the distinction between germ cells and somatic cells. More than a half-century later, Rostand (1943), aware of Spemann's suggestions, tried

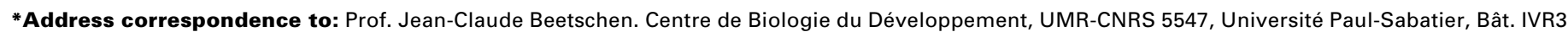
118 Route de Narbonne, 31062 Toulouse Cedex 04, France. FAX:+33-5-6155-6507. e-mail: beetsche@cict.fr

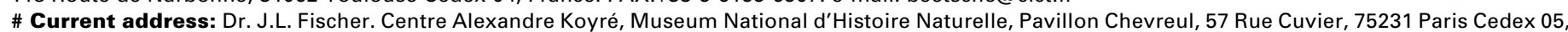
France
}

$0214-6282 / 2004 / \$ 25.00$

(C) UBC Press

Printed in Spain

www.ijdb.ehu.es 

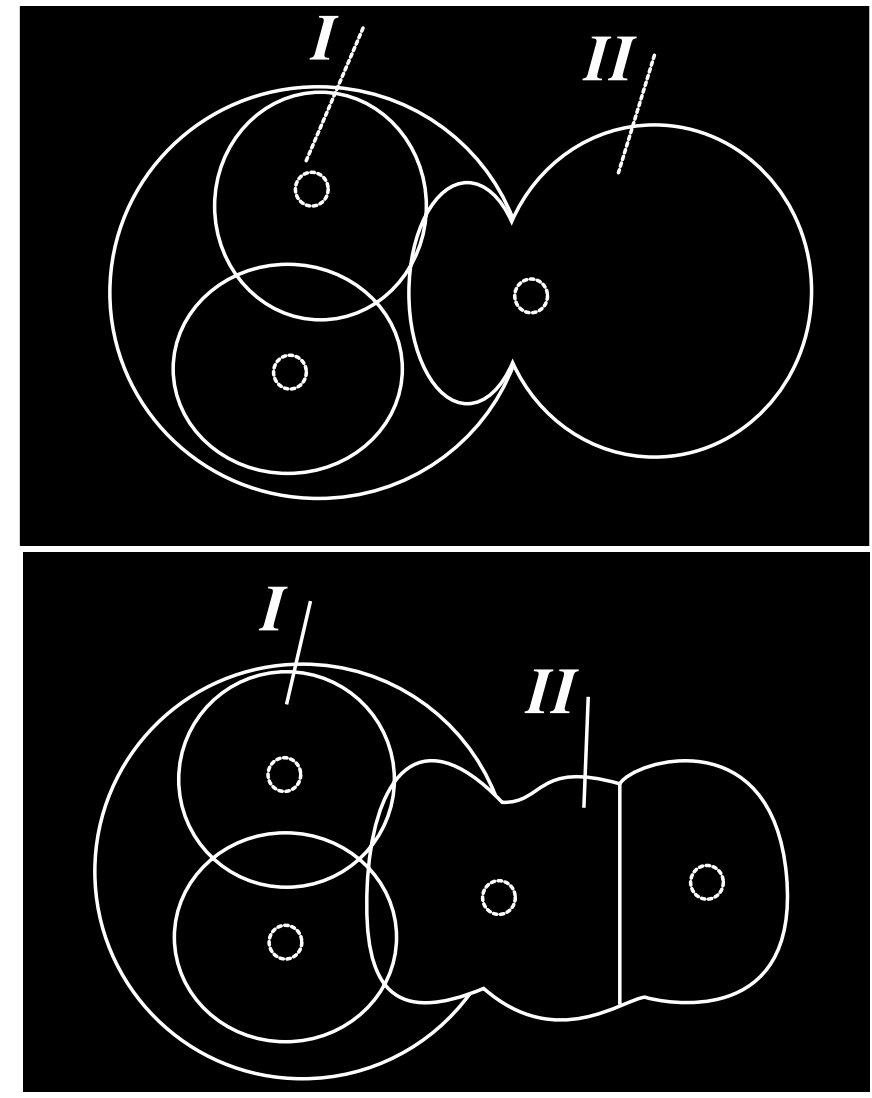

Fig. 1. Delayed nucleation experiment in the sea-urchin egg [adapted from Loeb (1894), Fig. 3 (top) and Fig. 4(bottom)]. (Top) A cleavage nucleus is moving into the cytoplasmic anucleate exovate (II), which now becomes independent of the main portion of the egg which started cleaving earlier (I), two blastomeres of which are drawn. (Bottom) The exovate starts cleaving (two cells) and will give rise to a twin embryo.

transplanting embryonic nuclei into frog eggs, but did not obtain conclusive results. Nevertheless, as emphasized by Mc Kinnell (1978), "he speculated in considerable detail on methodology of nuclear exchange [...] and considered the possibility of interspecific nucleocytoplasmic hybrids". Working on newt eggs, Lopashov (1945) was similarly unsuccessful in transplanting blastula nuclei. Finally, Briggs and King (1952), after solving numerous technical problems, successfully accomplished nuclear transplantation into frogs' eggs (Rana pipiens) for the first time. By improving their techniques, they obtained development of a high proportion (40 to 60 percent) of tadpoles from enucleated eggs injected with blastula nuclei, thereby providing evidence of developmental totipotency of those nuclei. The ability of cloned Ranatadpoles to metamorphose was demonstrated in later experiments (Briggs and King, 1960). The first cloned adults were obtained in another anuran, Xenopus laevis (Gurdon et al., 1958; Gurdon, 1962), but the proportion of injected eggs developing into apparently normal tadpoles was found to become increasingly reduced when the

* Note added in proof: A general review on nuclear transplantation in animals and related problems during the last 50 years has also been published by J.B.Gurdon and J.A.Byrne (2003) in Proc. Natl. Acad. Sci. USA 100: 8048-8052. transferred nuclei were taken from more and more advanced embryos. Very few adults were obtained with nuclei from differentiated cells. Early developmental abnormalities, resulting from several possible causes, were repeatedly observed by a number of authors, who extended all these results to several amphibian species. Detailed reviews of their contributions and discussions of the related problems were published in an informative book on amphibian cloning by Mc Kinnell (1978), who considered Spemann to be the initiator of the nuclear transfer technique.This viewpoint has continued to be repeated in several reports about cloning and corresponds to a widespread opinion among biologists (Mc Kinnell and DiBerardino,1999; DiBerardino, 2001; Klotzko, 2004)*.

In the following essay, we present evidence that the French biologist Yves Delage, whose writings had been overlooked by Mc Kinnell, expressed similar views on the use of nuclear transfer in studying cell differentiation as early as 1895. According to Delage's theory, early embryonic nuclei should be equivalent and retain the same potentialities as the nuclei of sex cells. His thoughts on this matter have already been briefly mentioned by one of us (Fischer, 1979), but that information has so far been disregarded in the scientific literature. We shall first reconsider Spemann's contributions to the problem at the beginning of the $20^{\text {th }}$ century, as well as the pioneering work by Loeb (1894) which may have led to the idea of nuclear transfer as a means of studying embryonic development.

\section{Loeb's experiments on delayed nucleation (1894)}

In 1891, Hans Driesch had demonstrated that a single blastomere separated from a sea-urchin egg at the 2-cell stage was able to develop into a smaller but normal pluteus larva and not into a partial larva, as was the case for the ascidian egg (Chabry, 1887). Similar results were obtained with blastomeres from the 4cell stage. This regulative phenomenon aroused wide interest (Sander, 1992). It showed that the first four blastomeres derived from the fertilized egg were equivalent to it and that each blastomere had the same overall potentialities. Jacques Loeb (1894) extended the analysis of this "equipotentiality". Ten minutes after an artificial fertilization, he placed sea-urchin eggs in hypotonic sea water (1 volume of distilled water added to 1 volume of sea water). The vitelline membrane of the egg burst and a cytoplasmic hernia was extruded through the opening, giving rise to an exovate that remained attached by a narrow pedicle to the main mass of the egg. That exovate contained the gamete nuclei and, subsequently, the zygotic nucleus. At first, the anucleate hernia failed to cleave, but after the egg had been transferred to normal sea water, a cleavage nucleus occasionally moved to the exovate, which subsequently developed into a second embryo (Fig. 1, corresponding to original Figs. 3 and 4 in Loeb's article). In some instances, Loeb obtained three or four embryos from the same egg with several exovates. Clearly, the daughter nuclei of the 2, 4- or 8-cell stages were still identical and had the same potentialities as the zygotic nucleus from which they originated. The results of Driesch and Loeb showed that these nuclei had not yet lost any of their overall hereditary properties, which was at variance with Weismann's theory. Nevertheless, whereas Loeb rightly believed that the egg cytoplasm was not divided into specialized territories, he still conceded that the cleavage nuclei should differ from each other with respect to their constituents. 

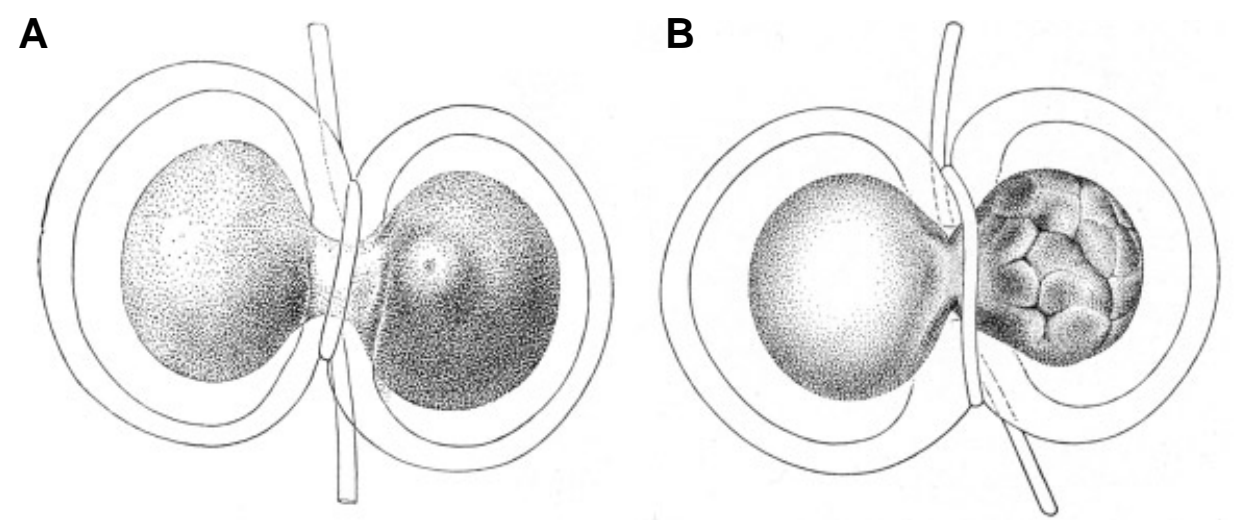

C

Fig. 2. Delayed nucleation experiment in the newt egg (adapted and modified from Spemann, 1928, 1936). (A) An uncleaved fertilized egg is constricted with a hair ligature; the zygotic nucleus will form in the right hand part, which shows the maturation spot with the $1^{\text {st }}$ polar body. (B) Several hours later, a nucleus from the cleaving right part (8-16 cell stage) is allowed to cross the cytoplasmic bridge and to move to the non-nucleated left part. (C) The separated left part of the egg has given rise to a morphologically normal embryo, whose development is delayed by several hours compared to the embryo forming from the right part.

This idea was, however, difficult to reconcile with the results of the twinning experiments. Loeb did not speculate on a possible extension of his results to nuclei from later embryonic stages, probably because when a nucleus from a 64-cell stage was involved in the re-nucleation after the hypotonic treatment, it led to abnormal skeletal formation and other developmental disorders in the twin embryo. Loeb also rightly emphasized that too small a volume of extruded cytoplasm would be unable, for mechanical reasons, to develop into a blastula.

\section{Spemann's delayed nucleation experiments $(1914,1928$, 1936)}

Following attempts by his student Otto Mangold to perform constriction experiments on fertilized newt eggs in 1913, Spemann (1914) published a short account of delayed nucleation experiments in similar uncleaved fertilized eggs that he had constricted with a fine hair ligature prior to the first division of the zygotic nucleus, which was included in one of the two parts united by a narrow cytoplasmic pedicle (Fig. 2A). A cleavage nucleus close to the constriction was later allowed to cross the cytoplasmic bridge by partly releasing the ligature (Fig. 2B). The formerly nonnucleated part then began to cleave, which led to formation of twin embryos in a number of cases (Fig. 2C). Since then, this experiment has been described and illustrated in most textbooks of developmental biology.

Spemann (1928) claimed that, when the idea of this experiment came to him, he had completely forgotten the similar results obtained by Loeb, whom he did not cite in his 1914 article. Later, in 1922 and 1923, he entrusted one of his students, Heinrich Schütz, with a systematic repetition of the ligature experiments, which were performed on approximately 250 eggs. Schütz submitted a typewritten doctorate dissertation in 1924, but did not publish his results. Spemann included them with those he had obtained in 1914, which he described in greater detail (Spemann,1928). The article dealt with dorsoventral and bilateral symmetry determination in the fertilized egg, in relationship with the location of the organizer field in the grey crescent, etc. The original protocols of the ligature and delayed nucleation experiments have all been recently re-examined and analyzed by
Fässler (1997, pp. 152-191). At this time, Spemann had not yet suggested attempting nuclear transfer from a later cleavage stage. This proposal was presented in his comprehensive book on experimental studies for a theory of development (Spemann, 1936), the English version of which appeared in 1938. In this book Spemann illustrated with many details the ligature and delayed nucleation experiments that were performed at the dawn of experimental embryology by himself and other authors (Spemann, 1936, pp.13-24). They were quoted again in a discussion on the "determination" concept (p.135), where there appeared the "fantastic" project to transfer a nucleus from a morula or, still better, from a differentiated cell, into an enucleated egg, provided that a suitable technique could be devised to extract the cell nucleus. The entire paragraph was cited in its English version by Mc Kinnell (1978, p.4) and DiBerardino (1987, p. 624). We will transcribe only its most significant sentences: "From the assumption of Weismann concerning the differential division of the nucleus, there would follow immediately a restriction of the potency of the genome; for if the germ plasm were separated during development into its constituent parts and distributed over the single cells of the body, it is evident that each of these cells would contain only its allotted portion and would lack all the remainder.[...] Decisive information about this question may perhaps be afforded by an experiment which appears, at first sight, to be somewhat fantastical. It has been shown, as pointed out before, in the egg of the sea-urchin (Loeb, 1894) and the newt (Spemann, 1914) that a piece of egg protoplasm which contains no nucleus may be induced to develop, may be "fertilized", as it were by a descendant of the fertilized egg nucleus.[...] Probably the effect could be attained if one could isolate the nuclei of the morula and introduce one of them into an eggoranegg fragment without an egg nucleus.....JThe experiment would have to be extended so that older nuclei of various cells could be used. This experiment might possibly show that even nuclei of differentiated cells can initiate normal development in the egg protoplasm". (Spemann, 1938, pp.210-211). We would just like to mention that the words "germ plasm" and "idioplasm" are used to translate the German "Erbmasse", which means "hereditary mass" and thus corresponds to the "germ plasm" (Keimplasma) of Weismann or the "idioplasm" of Naegeli. But Spemann did not use Weismann's word, which probably 


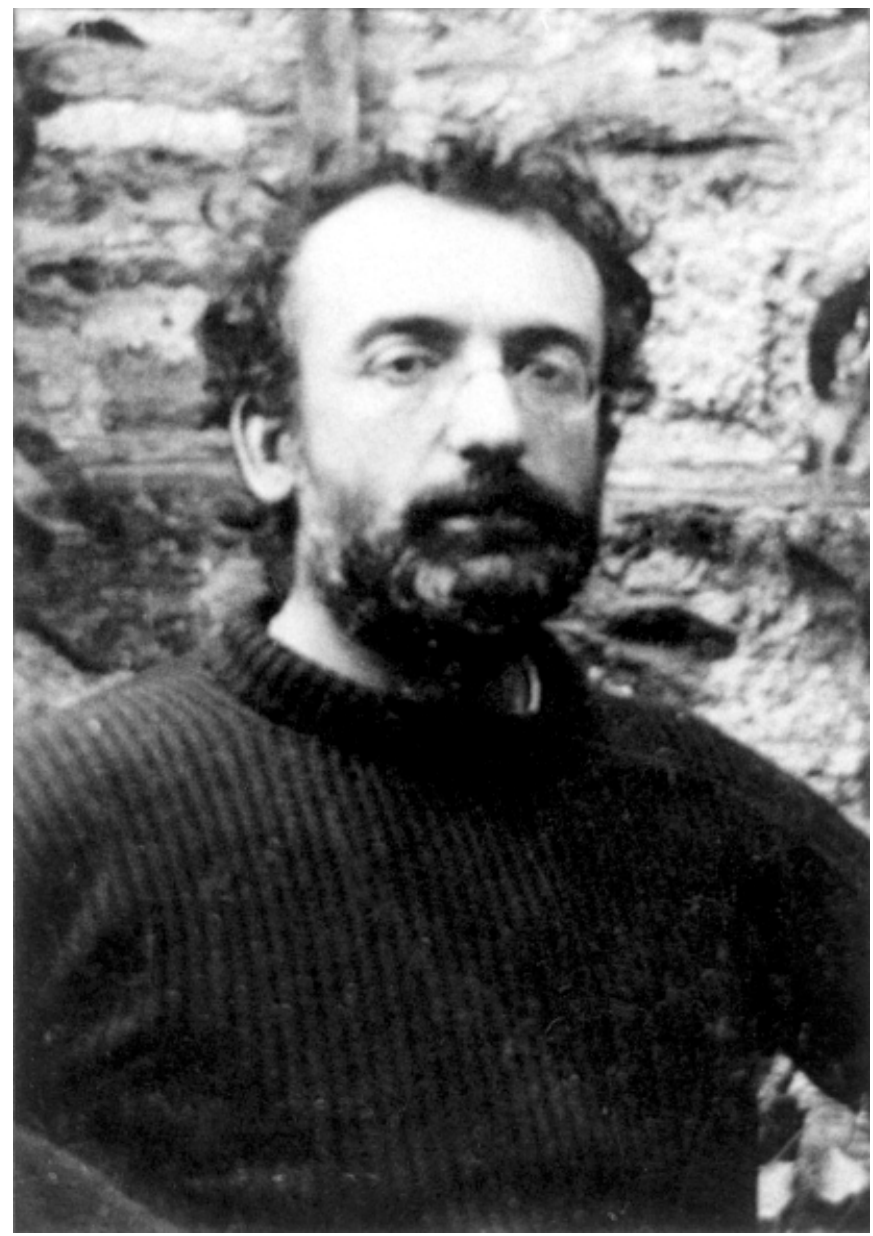

Fig. 3. Yves Delage (1854-1920) at the Roscoff marine laboratory. (From a photograph taken c.1905).

already sounded too obsolete and did not correspond to modern genetical views. Spemann's prediction about the possibility of obtaining normal development following the transfer of a nucleus from a differentiated cell now appears prophetic, even if it has proven difficult. However, we wish to make the point that similar predictions concerning nuclear transfer had been made quite independently much earlier by Delage (1895).

\section{Delage's proposal of nuclear transfer (1895)}

Yves Delage (1854-1920) was appointed Professor of Zoology in the Faculty of Sciences of Paris, at the Sorbonne, in 1885 . He then became the head of the Roscoff marine laboratory of the Paris Faculty in 1901 and he was elected to the Paris Academy of Sciences the same year (Fig. 3). Detailed accounts of his scientific career and of his commitments can be found in Fischer (1979, $1990,1995,1996)$ and in Paul (1985). One of his main contributions to embryology resides in his merogony experiments (anucleate cytoplasmic fragments of a single echinoderm egg were fertilized by spermatozoa and developed into larvae), which were followed by his demonstration of artificial parthenogenesis resulting from physical or chemical treatments; this was also one of the pioneer- ing topics of Loeb (Delage, 1899; Delage and Goldsmith, 1913). In 1895, Delage published a large book on "General Biology" entitled "La Structure du Protoplasma, les théories sur l'Hérédité et les grands problèmes de la Biologie générale". He strongly attacked the classical ideas on zoology that were still prevalent among his French colleagues and opposed them to the new achievements in general and experimental biology that were being obtained in other countries (e.g. Haeckel, O. and R. Hertwig, Weismann, Roux, Lankester, Van Beneden). This attack was partly unwarranted and revived a strong controversy with Alfred Giard, one of Delage's colleagues who held the Chair of Evolution in Paris University. The long-lasting quarrel between these two prominent biologists has been extensively documented by Paul (1985, pp.117-130). Anyhow, Delage's book was successful in France and a second edition was issued 1903, with a shortened modified title: "L 'Hérédité et les grands problèmes de la Biologie générale'. The specific passages that we shall refer to are identical in both editions.

With regard to developmental mechanisms, Delage was definitely an advocate of epigenetic processes, opposing the concepts of preformation or predetermination and, being an evolutionist, he still subscribed to neo-Lamarckian views, though he did not reject mendelian heredity (Fischer, 1979, 1996).

Delage considered that cell differentiation was a consequence of differences between the cytoplasmic components of two daughter cells issued from the same mother cell. The potential differences between their nuclei were considered to be an effect of the respective differences in the cytoplasmic environments. This theory opposed the views expressed by Weismann, Hertwig and Boveri, among others. Then Delage wrote a fairly short paragraph, which we translate as follows: "Every nucleus, at least at the beginning of ontogenesis, is a sex cell nucleus and if, without any deterioration, the egg nucleus could be replaced by the nucleus of an ordinary embryonic cell, we should probably see this egg developing without changes". (Delage, 1895, p.738; 1903, p.798). This is clearly a proposal for performing a nuclear transfer into an enucleated egg, but Delage did not give any indication about the possibility of devising adequate techniques to carry out such experiments.

\section{Discussion}

In the abovementioned paragraph, Delage thus predicted that an embryonic nucleus would be found to be equivalent to a zygotic nucleus if it could be transferred into an enucleated egg and, at the same time, would have the properties of a "sex cell nucleus". The latter statement anticipated experimental results that were obtained six decades later by two followers of Briggs and King, namely Subtelny and Bradt $(1960,1961,1963)$. These authors injected a blastula nucleus from the animal hemisphere into a mature, non-enucleated frog egg. The somatic blastula nucleus behaved like a diploid male pronucleus, giving rise, with its counterpart, the female haploid pronucleus, to a triploid fertilization nucleus. The egg subsequently developed into a triploid tadpole. On the other hand, contrary to Spemann (1936), Delage did not hypothesize that the nucleus of a differentiated cell might still be able to play the role of a zygotic nucleus.

In his 1895 book, Delage was already aware of the results of Loeb (1894) on delayed nucleation experiments. He made a few comments on them in a chapter dealing with the theoretical problem of egg "isotropy", a concept according to which there exist 
no qualitative spatial differences in the structures of the fertilized egg (Delage, 1895, p.331; 1903, p.353). Delage agreed with Loeb on the lack of predetermined portions of cytoplasm in the fertilized sea-urchin egg, i.e., on the isotropy of this egg, in contrast to the anisotropy of the ascidian egg (Chabry,1887; Fischer, 1992 a,b). However, Delage, in disagreement with Loeb, rightly believed that the cleavage nuclei were isotropic too, that is they were all similar and retained the same potentialities as the egg nucleus. The question now arises, as it does for Spemann's suggestion, as to whether or not Delage had been inspired by Loeb's experiments when he suggested replacing the zygotic nucleus by an embryonic nucleus to confirm the predicted identity of their developmental potentialities. There is no direct relationship between these two topics, which are discussed in two separate chapters in Delage's book. It is therefore impossible to answer this question. Nevertheless, Delage clearly imagined using nuclear transfer as a means of addressing the problem of nuclear changes in connection with cell differentiation and of testing Weismann's hypotheses in this respect. Spemann wanted to do the same thing a few years later. Delage's original and pioneering proposal was first recognized by Rostand (1962, p. 135) in a book for the layman, then mentioned again by Fischer (1979) in a historical article dealing with Delage's scientific concepts. However, it has so far been ignored in the scientific literature devoted to cloning experiments, in which Spemann's contribution is still considered a cornerstone, although neither Spemann nor Delage before him had dreamed of using nuclear transfer to obtain groups of genetically identical animals. At least, printed evidence is lacking in this respect. Similarly, is it possible that Spemann, who said (1928) that he had forgotten Loeb's experiment of delayed nucleation (1894) when he did the same in newt egg (1914), had read Delage's book? We believe not, because otherwise he would probably have evoked his nuclear transfer project earlier than 1936, especially when he described the delayed nucleation experiments in the newt egg with so much detail (1928). A cytological analysis of such constricted eggs was made by Fankhauser (1930), whose two drawings of sections with a cleavage nucleus close to the anucleate part of the egg were reproduced by Spemann (1936). Spemann's idea of nuclear transfer applied to embryonic or differentiated cell nuclei thus appears to be the result of a slow maturation.

\section{Conclusion}

Successful nuclear transfer techniques were considered essential for opening new roads towards the solution of a general problem: what are the respective contributions of cell nucleus and cytoplasm to heredity and development? These techniques were first devised in the frog egg by Briggs and King (1952), whose skill deserves admiration. Nuclear transfer through micromanipulation had been performed previously in a protozoan, Amoeba sphaeronucleus, by Comandon and De Fonbrune (1939), whose microforge was used to prepare micropipettes for experiments in amphibians. Delage (1895) was the first scientist to make correct predictions about the results of such experiments with animal eggs, but there is no trace of any attempt to perform them and his project fell into oblivion. Nevertheless, he should be mentioned as a pioneer of nuclear transfer, together with Spemann who, four decades later (1936), expressed similar views probably of his own, following his earlier experiments on delayed nucleation (1914), themselves similar to those of Loeb (1894). But neither Delage nor Spemann explicitly wrote that this technique could be used to give rise to genetically identical animals. Their proposals were inspired by fundamental problems of development and cell differentiation. It thus seems inappropriate to state that cloning a vertebrate was first proposed by Spemann who, moreover, has been recently qualified as a Nazi scientist in this respect (e.g., Kahn and Papillon, 1998; repeated in several web sites devoted to cloning). This view on Spemann's political convictions was the subject of some discussion (Fankhauser, 1972; Horder and Weindling, 1987) but has been more recently disproved by Fässler (1997), after an extensive analysis of Spemann's correspondence and other publications, from which it appears that Spemann was at variance with many official Nazi statements.

\section{Acknowledgements}

We wish to express our sincere thanks to Professors Julian Smith (Toulouse) and George Malacinski (Bloomington) who improved the English text and made helpfulsuggestions, to DrMarcMoreau(Toulouse) who provided Delage's portrait, to Chantal Michel for her help in collecting articles and to Bruno Savelli, who adapted the figures.

\section{References}

BRIGGS, R. and KING, T.J. (1952). Transplantation of living nuclei from blastula cells into enucleated frogs' eggs. Proc. Nat. Acad. Sc. USA 38: 455-463.

BRIGGS, R. and KING, T.J. (1960). Nuclear transplantation studies on the early gastrula (Rana pipiens). I. Nuclei of presumptive endoderm. Dev. Biol. 2:252-270.

CHABRY, L. (1887). Embryologie normale et tératologique des Ascidies. Félix Alcan, Paris.

COMANDON, J. and DE FONBRUNE, P. (1939). Greffe nucléaire totale, simple ou multiple, chez une amibe. C. R. Soc. Biol. Paris 130: 744-748.

DELAGE, Y. (1895). La Structure du Protoplasma, les théories de l'Hérédité et lesgrands problèmes de la Biologie générale. Schleicher, Paris.

DELAGE, Y. (1899). Etudes sur la mérogonie. Arch. Zool. exp. gén. 7: 383-417.

DELAGE, Y. (1903). L'Hérédité et les grands problèmes de la Biologie générale (2nd edition of the 1895 book). Reinwald and Schleicher, Paris.

DELAGE, Y. and GOLDSMITH, M. (1913). La Parthénogenèse naturelle et expérimentale. Flammarion, Paris.

DI BERARDINO, M. A. (1987). Genomic potential of differentiated cells analyzed by nuclear transplantation. Amer. Zool. 27: 623-644.

DI BERARDINO, M. A. (2001). Animal cloning-the route to new genomics in agriculture and medicine. Differentiation 68: 67-83.

DRIESCH, H. (1891). Entwicklungsmechanische Studien. I. Der Werth der beiden ersten Furchungszellen in der Echinodermenentwicklung. Experimentelle Erzeugung von Teil und Doppelbildungen. Z. wiss. Zool. 53: 160-178 and 183184.

FAESSLER, P.E. (1997). Hans Spemann 1869-1941. Experimentelle Forschung im Spannungsfeld von Empirie und Theorie. Springer, Berlin-Heidelberg-New York.

FANKHAUSER, G. (1930). Zytologische Untersuchungen an geschnürten TritonEiern. I. Die verzögerte Kernversorgung einer Hälfte nach hantelförmiger Einschnürung des Eies. W. Roux' Arch. Entw. mech. 122: 116-139.

FANKHAUSER, G. (1972). Memories of great embryologists. Reminiscences of F.Baltzer, H. Spemann, F.R. Lillie, R.G. Harrison and E.G. Conklin. Amer. Sc. 60: 46-55.

FISCHER, J. L. (1979). Yves Delage (1854-1920): l'épigenèse néo-lamarckienne contre la prédétermination weismannienne. Rev. Synthèse, 3ème sér., $n^{\circ}$ 95-96, 100: 443-461.

FISCHER, J. L. (1990). Experimental embryology in France (1887-1936). Int. J. Dev Biol. 34: 11-23.

FISCHER, J.L. (1992 a). The embryological œuvre of Laurent Chabry. Roux's Arch. Dev. Biol. 201: 125-127. 
FISCHER, J.L. (1992 b). How to dart ascidian blastomeres: the embryological micro-tools of Laurent Chabry (1855-1893). Roux's Arch. Dev. Biol. 201: 191 193.

FISCHER, J.L. (1995). Yves Delage (1854-1920) and the ideology behind his research on "fécondation". Roux's Arch. Dev. Biol. 204: 219-222.

FISCHER, J.L. (1996). Article "Delage". In Dictionnaire du Darwinisme et de I'Evolution. (Edit. P. Tort).Vol. 1, pp. 1160-1164. P.U.F., Paris.

GURDON, J.B. (1962). Adult frogs derived from the nuclei of single somatic cells. Dev. Biol. 4: 256-273.

GURDON, J.B., ELSDALE, T.B. and FISCHBERG, M. (1958). Sexually mature individuals of Xenopus laevis from the transplantation of single somatic nuclei. Nature 182: 64-65.

HORDER,T.J. and WEINDLING, P.J. (1987). Hans Spemann and the organiser. In A History of Embryology (Ed. T.J. Horder, J.A. Witkowsky and C.C. Wylie), British Soc Dev. Biol. Symposium 8: 183-242. Cambridge Univ. Press, Cambridge and New York.

KAHN, A. and PAPILLON, F. (1998). Copies conformes, le clonage en question. NiL, Paris.

KLOTZKO, A.J. (2004). A clone of your own? The science and ethics of cloning. Oxford Univ. Press, Oxford and New York.

LOEB, J. (1894). Ueber eine einfache Methode, zwei oder mehr zusammengewachsene Embryonen aus einem Ei hervorzubringen. Pflügers Arch. 55: 525-530.

LOPASHOV, G.V. (1945). Experimental studies on potencies of nuclei from newt blastulae by means of transplantation. Ref. Rab. Biol. Otd. Akad. Nauk. SSSR : 88-89 (cited in McKinnell, 1978).

Mc KINNELL, R.G. (1978). Cloning. Nuclear transplantation in Amphibia. Univ. Minnesota Press, Minneapolis.

Mc KINNELL, R.G. and DI BERARDINO, M.A. (1999). The biology of cloning: history and rationale. BioScience 49: 875-885.

PAUL, H.W. (1985). From Knowledge to Power. The rise of the science empire in France 1860-1939. Cambridge Univ. Press, Cambridge and New York.
RAUBER, A. (1886). Personaltheil und Germinaltheil des Individuum. Zool. Anz. 9: 166-171.

ROSTAND, J. (1943). Essai d'inoculation de noyaux embryonnaires dans l'œuf vierge de grenouille. Parthénogenèse ou fécondation? Rev. scientif. 81: 454-456.

ROSTAND, J. (1962). Aux frontières du surhumain. Gallimard, Paris.

SANDER, K. (1992). Shaking a concept: Hans Driesch and the varied fates of seaurchin blastomeres. Roux's Arch. Dev. Biol. 201: 265-267.

SPEMANN, H. (1914). Ueber verzögerte Kernversorgung von Keimteilen. Verhandl. dtsch. Zool. Ges. (Freiburg) 24: 216-221.

SPEMANN, H. (1928). Die Entwicklung seitlicher und dorso-ventraler Keimhälften be verzögerter Kernversorgung. Z. wiss. Zool. 132: 105-134.

SPEMANN, H. (1936). Experimentelle Beiträge zu einer Theorie der Entwicklung Springer, Berlin.

SPEMANN, H. (1938). Embryonic development and induction. Yale Univ. Press, New Haven.

SUBTELNY, S. and BRADT, C. (1960). Transplantation of blastula nuclei into activated eggs from the body cavity and the uterus of Rana pipiens. I. Evidence for fusion between the transferred nucleus and the female nucleus of the recipient egg. Dev. Biol. 2: 393-407.

SUBTELNY, S. and BRADT, C. (1961). -ld-. II. Development of the recipient body cavity eggs. Dev. Biol. 3: 96-114.

SUBTELNY, S. and BRADT, C. (1963). Cytological observations on the early developmental stages of activated Rana pipiens eggs receiving a transplanted blastula nucleus. J. Morphol. 112: 45-59.

WEISMANN, A. (1892). Das Keimplasma. Eine Theorie der Vererbung. Fischer, Jena.

WEISMANN, A. (1893). The germ-plasm: a theory of heredity (English translation of the preceding reference). Walter Scott, London.

Received: April 2004 Reviewed by Referees: May 2004 Modified by Authors and Accepted for Publication: June 2004 